\title{
Early-life exposure to endocrine disrupting chemicals associates with childhood obesity
}

Chunxue Yang, $\mathrm{MS}^{1}$, Hin Kiu Lee, BS $\mathrm{BS}^{1,2}$, Alice Pik Shan Kong, $\mathrm{PhD}^{3,4,5}$, Lee Ling Lim, $\mathrm{PhD}^{3,6,7}$, Zongwei Cai, $\mathrm{PhD}^{1,2}$, Arthur C.K. Chung, $\mathrm{PhD}^{1,2}$

'State Key Laboratory of Environmental and Biological Analysis, Department of Chemistry, Hong Kong Baptist University, Hong Kong SAR, China, ${ }^{2} \mathrm{HKBU}$ Institute for Research and Continuing Education, Shenzhen, China, ${ }^{3}$ Department of Medicine and Therapeutics, ${ }^{4}$ Li Ka Shing Institute of Health Sciences, ${ }^{5}$ Hong Kong Institute of Diabetes and Obesity, The Chinese University of Hong Kong, Prince of Wales Hospital, Hong Kong SAR, China, ${ }^{6}$ Department of Medicine, Faculty of Medicine, University of Malaya, Kuala Lumpur, Malaysia, ${ }^{7}$ Asia Diabetes Foundation, Hong Kong SAR, China

Received: 24 November, 2018 Revised: 14 December, 2018

Accepted: 18 Devember, 2018

Address for correspondence: Arthur C.K. Chung, Ph.D

Partner State Key Laboratory of Environmental and Biological Analysis, The Hong Kong Baptist University, 224, Waterloo Road, Kowloon Tong, Hong Kong, China

Tel: +852-34112253

Fax: +852-34112285

E-mail: chungack@hkbu.edu.hk https://orcid.org/0000-0003-15197224

Address for co-correspondence: Zongwei Cai, Ph.D

Partner State Key Laboratory of Environmental and Biological Analysis, The Hong Kong Baptist University, 224, Waterloo Road, Kowloon Tong, Hong Kong, China

Tel: +852-34116673

Fax: +852-34112285

E-mail : zwcai@hkbu.edu.hk https://orcid.org/0000-0002-87247684
Increasing prevalence of childhood obesity poses threats to the global health burden. Because this rising prevalence cannot be fully explained by traditional risk factors such as unhealthy diet and physical inactivity, early-life exposure to endocrine disrupting chemicals (EDCs) is recognized as emerging novel risk factors for childhood obesity. EDCs can disrupt the hormone-mediated metabolic pathways, affect children's growth and mediate the development of childhood obesity. Many organic pollutants are recently classified to be EDCs. In this review, we summarized the epidemiological and laboratory evidence related to EDCs and childhood obesity, and discussed the possible mechanisms underpinning childhood obesity and early-life exposure to non-persistent organic pollutants (phthalates, bisphenol A, triclosan) and persistent organic pollutants (dichlorodip henyltrichloroethane, polychlorinated biphenyls, polybrominated diphenyl ethers, per- and polyfluoroalkyl substances). Understanding the relationship between EDCs and childhood obesity helps to raise public awareness and formulate public health policy to protect the youth from exposure to the harmful effects of EDCs.

Keywords: Endocrine disrupting chemicals, Childhood obesity, Persistent organic pollutants, Early-life exposure

\section{Introduction}

Childhood obesity is increasingly recognized as an important health hazard. In addition to the social stigma and psychological consequences, obesity is associated with increased risk of type 2 diabetes mellitus, hypertension, hyperlipidemia, sleep apnea, cardiovascular disease, cancer and arthritis. ${ }^{1)}$ There is also growing evidence showing that childhood obesity may herald adult obesity. ${ }^{2-6)}$ The Global Burden of Diseases study recently estimated that nearly 110 million children and adolescents were obese. ${ }^{7)}$ Alarmingly, the prevalence of youth that are overweight and obesity has doubled in the last three decades, with its rate of increase greater than that of adult obesity in most countries.")

Unhealthy diet and physical inactivity are traditional risk factors for obesity. Greater energy intake than energy expenditure results in positive energy balance and obesity. ${ }^{8)}$ However, lifestyle and genetic factors are unable to fully explain the rising prevalence and incidence of overweight or obese children. ${ }^{9,10)}$ Growing evidence from epidemiological studies indicates that exposure to environmental chemical pollutants may contribute to this global epidemic of childhood obesity. ${ }^{11-13)}$ Children who have early exposure to these pollutants even during intrauterine period may experience either an increase in body weight at young age or a catchup increase of body weight in later life. ${ }^{14,15)}$

\section{Endocrine disrupting chemicals}

Endocrine disrupting chemicals (EDCs) are a class of environmental pollutants that affect 
the endocrine function and modulate our risk of developing metabolic diseases including obesity. ${ }^{16)}$ EDCs include organic chemicals (such as nonpersistent organic chemicals and persistent organic pollutants [POPs]) and its analogs (such as alkylphenols). They are mainly man-made chemicals or compounds which are widely found in food, daily use products/ materials, and the environment (such as water, indoor air, and dust), that can accumulate in human body through the food chain. ${ }^{17-19)}$ Intraplacental transfer, breast milk consumption and children's hand to mouth behavior are the common ways that infancy and young children are exposed to EDCs in early-life. Table 1 summarizes the characteristics of some EDCs.

Emerging epidemiological and biological evidence suggests that rapid weight gain during infancy or later childhood might be related to maternal or early-life exposure to EDCs. ${ }^{20-22)}$ In this review, we discuss this interesting relationship and the potential mechanisms.

\section{Nonpersistent organic chemicals}

Nonpersistent organic chemicals have a short half-life in the range of less than 24 hours to one week and include phthalates, bisphenol A and triclosan.

\section{Phthalates}

Phthalates (phthalate esters) are a family of esters of phthalic acid and are mainly used as plasticizers to soften polyvinyl chloride or increase the durability and longevity of consumer products (such as containers and plastics) (Table 1). Phthalates can be found in food, pharmaceutical, cosmetic ${ }^{23)}$ and baby caring products. ${ }^{2425)}$ Ingestion, respiration or dermal absorption are the routes for phthalates exposure. ${ }^{26,27)}$ Compared to high molecular weight (HMW) congeners (such as DEHP [di-2ethylhexyl phthalate], DnOP [di-n-octyl phthalate]), ${ }^{28)}$ low molecular weight (LMW) phthalates (such as DEP [diethyl phthalate], DnBP [di-n-butyl phthalate], and DiBP [diiso-butyl phthalate]) have higher bioaccumulation factors, which may lead to high concentration within the body and increase the health risk. ${ }^{29)}$ In many developed countries, LMW phthalates have been gradually replaced by HMW phthalates or nonphthalates plasticizers for health concerns. ${ }^{30)}$ However, LMW phthalates (such as DEP, a common solvent for fragrance) are still frequently detected in consumer products. ${ }^{31)}$

Urinary or serum phthalates and their metabolites have been found to be significantly associated with body size and body mass index (BMI) in children and adolescents based on epidemiology studies ${ }^{32-36)}$ (Table 2). A 4-year prospective study involving 1,239 girls in the United States (US) showed that early exposure to high concentration of LMW phthalates (MEP [monoethyl], MBP [mono-n-butyl], MiBP [mono-isobutyl]) at age $6-8$ years were positively associated with weight gain $\left(\beta=1.2,95 \%\right.$ confidence interval $\left.[\mathrm{CI}], 0.41-2.1 \mathrm{~kg} / \mathrm{m}^{2}\right)$ and increased waist circumference $(\beta=3.9,95 \%$ CI, $1.3-6.5 \mathrm{~cm})$ than later exposure at age $7-13$ years. ${ }^{37)}$ Furthermore, MEHP (mono-(2-ethylhexyl) phthalate), the urinary metabolites of DEHP, were positively correlated with fasting glucose to insulin ratio (FGIR) (Spearman's correlation coefficient, 0.341; $P=0.039) .{ }^{38)}$ DEHP exposure in female mice was associated with increased abdominal visceral fat accumulation in the offspring. ${ }^{39)}$ However, another Spanish birth cohort study reported that high maternal urine HMW phthalates (including MBzP [mono-benzyl phthalate], MEHP, MEHHP [mono(2ethyl-5-hydroxyhexyl) phthalate], MEOHP [mono(2-ethyl-5oxohexyl) phthalate], and MECPP [mono(2-ethyl-5-carboxypentyl) phthalate]) was negatively associated with body weight $z$-score in infants aged $0-6$ months $(\beta=-0.41,95 \% \mathrm{CI},-0.75$ to $-0.06),{ }^{40)}$ Therefore, more studies are needed to delineate the potential effects of phthalates on childhood obesity taking sex

Table 1. Characteristics of endocrine disrupting chemicals (EDCs) related to childhood obesity

\begin{tabular}{|c|c|c|c|}
\hline EDCs & Biological half-life & Usage & Route of exposure \\
\hline Phthalates & $<24$ hours & $\begin{array}{l}\text { PVC plastics, food package, synthetic leather, toys, scent retainer } \\
\text { personal care products, adhesives }\end{array}$ & $\begin{array}{l}\text { Ingestion, respiration, dermal absorption, } \\
\text { placenta transfer }\end{array}$ \\
\hline BPA & $\sim 6$ hours & $\begin{array}{l}\text { Consumer plastics and polycarbonate products (such as water } \\
\text { bottles, plastic food containers and cans), and medical materials } \\
\text { (such as dental fillings) }\end{array}$ & Oral absorption, placenta transfer \\
\hline Triclosan & $<24$ hours & $\begin{array}{l}\text { Antimicrobial soaps, personal care products, toothpaste, cleaning } \\
\text { products }\end{array}$ & Oral and dermal absorption; placenta transfer \\
\hline DDT & $\sim 20-30$ years & Organochlorine pesticides & $\begin{array}{l}\text { Diet ingestion and respiration, dermal absorption, } \\
\text { placenta and breastfeeding transfer }\end{array}$ \\
\hline PCBs & $\sim 10$ years & $\begin{array}{l}\text { Industrial production (such as transformers and large capacitors), } \\
\text { nominally closed systems (such as hydraulic fluids and lubricants) } \\
\text { and open applications (such as carbon-less copy paper) }\end{array}$ & $\begin{array}{l}\text { Diet ingestion and respiration, dermal absorption, } \\
\text { placenta and breastfeeding transfer }\end{array}$ \\
\hline PBDES & 1.8-11.7 years & $\begin{array}{l}\text { Used as flame retardant in many products, such as building } \\
\text { materials, electronics, furnishings, motor vehicles, airplanes, } \\
\text { plastics, polyurethane foams, and textiles }\end{array}$ & $\begin{array}{l}\text { Diet ingestion, respiration and dermal absorption, } \\
\text { placenta and breastfeeding transfer }\end{array}$ \\
\hline PFASs & $3.8-7.3$ years & $\begin{array}{l}\text { Stain- or oil-resistant coating materials for textiles, carpet, food } \\
\text { containers, fire-fighting foams and industrial surfactants }\end{array}$ & $\begin{array}{l}\text { Age-related behavioral contact and diet } \\
\text { ingestion, placenta and breastfeeding transfer }\end{array}$ \\
\hline
\end{tabular}

BPA, bisphenol A; DDT, dichlorodiphenyltrichloroethane; PCB, polychlorinated biphenyl; PBDE, polybrominated diphenyl ether; PFAS, Per- and polyfluoroalkyl substance. 
into consideration.

\section{Bisphenol A}

Bisphenol A (BPA) belongs to bisphenols, a group of chemical compounds with 2 hydroxyphenyl functionalities. BPA is commonly used in consumer plastics and polycarbonate products (such as water bottles, plastic food containers, and cans), as well as medical materials (such as dental fillings) (Table 1). Oral absorption is the major exposure pathway because BPA can leak into food and beverage from containers. ${ }^{41-43)}$ Its short biological half-life (about 6 hours) allows for easy detection of BPA and its conjugates in urine. ${ }^{44)}$

Table 2 summarizes the cross-sectional and prospective cohort studies that have examined the relationship between exposure to BPA and risk of childhood obesity. In the Columbia Center for Children's Environmental Health birth cohort study, increased exposure to BPA in children aged 7 years was associated with high fat mass index, body fat and waist circumference $^{45)}$ (Table 2). Maternal BPA concentration was shown to be associated with increased plasma leptin levels in boys. ${ }^{46)}$ Some cross-sectional studies has found that early-life exposure to BPA is positively associated with obesity in children and adolescents (Table 2). ${ }^{47,48)}$

In rats, perinatal exposure to BPA promotes adipogenesis and weight gain. ${ }^{49,50)}$ Results from a mouse study also revealed that exposure to BPA during fetal period led to age-related increase in body weight due to an increase in adipose tissue mass and volume. $^{51)}$

Several BPA substituents such as bisphenol F (BPF) and bisphenol S (BPS) are currently available. However, these substituents have a wide spectrum of toxicities with potential endocrine-disrupting effects, particularly BPS which has been shown to be as hormonally active as BPA. ${ }^{52,53)}$ However, a study of 1,521 participants aged 20 years or older in the US reported that only urinary BPA was significantly associated with obesity, but not BPF or BPS. ${ }^{54)}$ Continued biomonitoring of bisphenols and evaluation of their health effects in human are warranted.

\section{Triclosan}

Triclosan (2,4,4'-trichloro-2'-hydroxy-diphenyl ether) is an antibacterial reagent commonly found in pharmaceuticals

Table 2. Epidemiological evidence for the association among EDCs and childhood obesity

\begin{tabular}{|c|c|c|c|c|c|}
\hline Author/Year & $\begin{array}{l}\text { Population/ } \\
\text { study design }\end{array}$ & Location & Objects & Measured EDCs & Outcome (IDR/aOR; 95\% CI) \\
\hline Buser $^{321} / 2014$ & $\begin{array}{c}\text { NA/cross- } \\
\text { sectional study }\end{array}$ & United States & $6-19$ years old & $\begin{array}{l}\text { Phthalates: MnBP, MEP, } \\
\text { MiBP, MECPP, MEHHP, } \\
\text { MEOHP, MEHP, MBzP, } \\
\text { MCNP, MCOP }\end{array}$ & $\begin{array}{l}\text { LMP (MnBP, MEP, and MiBP) are significantly } \\
\text { associated with higher odds for obesity in male } \\
\text { children in second, third and highest quartiles } \\
\text { (aOR, 2.96; 95\% Cl, 1.66-5.30; aOR, 2.80; } 95 \% \mathrm{Cl} \text {, } \\
\text { 1.60-4.90; aOR, 2.84; 95\% Cl, 1.40-5.78) and } \\
\text { adolescents in second, third and highest } \\
\text { quartiles (aOR, 3.97; 95\% Cl, 2.23-7.08; aOR, 3.13; } \\
\text { 95\% Cl, 1.69-5.81; aOR, 5.39; 95\% Cl, 1.87-15.53). }\end{array}$ \\
\hline Zhang $^{33)} / 2014$ & $\begin{array}{c}\text { 593/cross } \\
\text {-sectional study }\end{array}$ & Shanghai, China & $\begin{array}{l}\text { School-aged } \\
\text { children }\end{array}$ & $\begin{array}{l}\text { Phthalates: MEP, MBP, } \\
\text { MMP, MEHP, MEOHP, } \\
\text { MEHHP }\end{array}$ & $\begin{array}{l}\text { Urinary concentrations of MBP and sum of LMP } \\
\text { was positively associated with obesity in boys } \\
\text { (OR, 5.768; } 95 \% \mathrm{Cl}, 1.622-20.515 ; \mathrm{OR}, 6.841 ; 95 \% \\
\mathrm{Cl}, 2.073-22.575) \text {, while concentrations of } \\
\text { MEOHP (OR, 0.092; } 95 \% \mathrm{Cl}, 0.009-0.958) \text {, MEHHP } \\
\text { (OR, } 0.084 ; 95 \% \mathrm{Cl}, 0.008-0.910) \text {, and sum of DEHP } \\
\text { metabolites (gMEHP) (OR, } 0.078 ; 95 \% \mathrm{Cl}, 0.008- \\
\text { 0.791) were negatively associated with girls' } \\
\text { obesity. }\end{array}$ \\
\hline $\mathrm{Kim}^{34)} / 2015$ & $\begin{array}{l}\text { 128/cohort } \\
\text { study }\end{array}$ & Republic of Korea & $\begin{array}{l}\text { Healthy } \\
\text { pregnant } \\
\text { women and } \\
\text { newborns }\end{array}$ & $\begin{array}{l}\text { DEHP metabolites: } \\
\text { MEHHP, MEOHP }\end{array}$ & $\begin{array}{l}\text { MEHHP and MEOHP were positively associated } \\
\text { with triglyceride levels }\left(\beta^{*}=0.15,95 \% \mathrm{Cl}, 0.024-\right. \\
0.267 ; \beta=0.13,95 \% \mathrm{Cl}, 0.009-0.256) \text {; total urinary } \\
\text { DEHP was positively associated with triglyceride } \\
\text { ( } \beta=0.14,95 \% \mathrm{Cl}, 0.020-0.267) ; \text { besides, urinary } \\
\text { DEHPs were positively associated with the BMI } \\
\text { z-scores of new born (first } 3 \text { month) (OR, } 4.35 \text {; } \\
95 \% \mathrm{Cl}, 1.20-15.72) \text {. Both MEHHP and MEOHP } \\
\text { showed increased OR for body mass increase } \\
\text { over the 50th centile (OR, 4.43; } 95 \% \mathrm{Cl}, 1.22- \\
\text { 16.04; OR, 3.91; } 95 \% \mathrm{Cl}, 1.12-13.65) \text {. }\end{array}$ \\
\hline Hatch $^{35)} / 2008$ & $\begin{array}{l}4,369 / \text { cohort } \\
\text { study }\end{array}$ & United States & 2-59 years old & $\begin{array}{l}\text { Phthalates: MEP, MEHP, } \\
\text { MBP, MBzP, MEHHP, } \\
\text { MEOHP }\end{array}$ & $\begin{array}{l}\text { MEHP was inversely related to BMI in adolescent } \\
\text { girls (adjusted mean } \mathrm{BMI}=25.4,23.8 ; 95 \% \mathrm{Cl} \text {, } \\
\text { 23.4-22.9) }\end{array}$ \\
\hline
\end{tabular}


Table 2. Epidemiological evidence for the association among EDCs and childhood obesity (continued)

\begin{tabular}{|c|c|c|c|c|}
\hline Author/Year & $\begin{array}{l}\text { Population/ } \\
\text { study design }\end{array}$ & Location & Objects & Measured EDCs \\
\hline $\begin{array}{l}\text { Teitelbaum }{ }^{36)} \\
\text { /2012 }\end{array}$ & $\begin{array}{l}\text { 521/cohort } \\
\text { study }\end{array}$ & New York & $\begin{array}{l}\text { 6-8 years } \\
\text { ol d children }\end{array}$ & $\begin{array}{l}\text { Phthalates: low MWP: } \\
\text { MEP, MBP and MiBP; high } \\
\text { MWP: MECPP, MEHHP, } \\
\text { MEOHP, MEHP and MBzP }\end{array}$ \\
\hline $\begin{array}{l}\text { Hoepner }^{45)} \\
/ 2016\end{array}$ & $\begin{array}{l}\text { 375/birth } \\
\text { cohort }\end{array}$ & United States & $\begin{array}{l}\text { Pregnant mother } \\
\text { and their child } \\
\text { (age 3-7 years) }\end{array}$ & BPA \\
\hline $\begin{array}{l}\text { Volberg } \\
/ 2013\end{array}$ & $\begin{array}{l}\text { 188/longitudinal } \\
\text { cohort study }\end{array}$ & $\begin{array}{c}\text { California, } \\
\text { United States }\end{array}$ & $\begin{array}{l}\text { Pregnant women } \\
>18 \text { years of } \\
\text { age, }<20 \text { weeks } \\
\text { gestation and } \\
\text { their child }\end{array}$ & BPA \\
\hline
\end{tabular}

\begin{tabular}{|c|c|c|c|c|}
\hline $\begin{array}{l}\text { Trasande }{ }^{47)} \\
\text { /2012 }\end{array}$ & $\begin{array}{c}2,838 / \text { cross } \\
\text { sectional study }\end{array}$ & United States & Age 6-19 years & BPA \\
\hline Wang $^{48)} / 2012$ & $\begin{array}{c}2,921 / \text { cross- } \\
\text { sectional study }\end{array}$ & Shanghai, China & Age 8-15 years & BPA \\
\hline
\end{tabular}

$\begin{array}{cccc}2,898 & \text { United States } & \text { Children (6-19 } \\ \text { /cohort study } & \text { years old }) & \text { Triclosan } & \text { U }\end{array}$

Urinary triclosan was associated with aOR 0.34 ( $95 \% \mathrm{Cl}, 0.05-0.64) \mathrm{kg} / \mathrm{m}^{2}$ lower level of BMl and $0.92(95 \% \mathrm{Cl}, 0.09-1.74) \mathrm{cm}$ smaller waist circumference in boys, and a $0.62(95 \% \mathrm{Cl}, 0.31-$ $0.94) \mathrm{kg} / \mathrm{m}^{2}$ lower level of BMl and $1.32(95 \% \mathrm{Cl}$, $0.54-2.09) \mathrm{cm}$ smaller waist circumference in girls.

Tang$\begin{array}{lr}\text { Tang- } & \text { 640/prospective } \\ \text { Péronard }^{72)} & \text { cohort study }\end{array}$ Faroe Islands Pregnant women PCBs $(138,153$, and 180) who gave birth between November 1997 to March 2000 and DDE /2014

\begin{tabular}{|c|c|c|c|c|c|}
\hline Valvi $^{73)} / 2014$ & $\begin{array}{l}\text { 2,150/birth } \\
\text { cohort study }\end{array}$ & Spanish & $\begin{array}{l}\text { Pregnant women } \\
\text { (>16 years) }\end{array}$ & $\begin{array}{l}\text { DDT, DDE, HCB, } \\
\text { B-hexachlorocyclohexane, } \\
\text { and PCB congeners 28, } \\
\text { 52, 101, } 118,138,153, \\
\text { and } 180\end{array}$ & $\begin{array}{l}\text { The serum concentration (ng/g lipid) of DDE in } \\
\text { pregnancy is about } 132 \pm 2.4 \text {. Serum DDE was } \\
\text { positively associated with the rapid growth in the } \\
\text { total populations ( } \beta=1.13 ; 95 \% \mathrm{Cl}, 1.01-1.26) \text {, } \\
\text { and overweight at } 14 \text { months age }(\beta=1.15 ; 95 \% \\
\mathrm{Cl}, 1.03-1.28) \text {. }\end{array}$ \\
\hline Warner $^{74)} / 2014$ & $\begin{array}{c}601 / \text { longitudinal } \\
\text { birth cohort study }\end{array}$ & $\begin{array}{c}\text { California, } \\
\text { United States }\end{array}$ & $\begin{array}{c}\text { Pregnant women } \\
\text { (>18 years), their } \\
\text { newborns ( } 1-7 \\
\text { years) }\end{array}$ & $\begin{array}{c}o, p^{\prime}-\mathrm{DDT}, p_{1} p^{\prime}-\mathrm{DDT}, \\
p, p^{\prime}-\mathrm{DDE}\end{array}$ & $\begin{array}{l}\text { Among boys, } 10 \text {-fold increases in prenatal DDT } \\
\text { and DDE concentrations were associated with } \\
\text { increased odds of becoming overweight or obese } \\
\text { (for o, } p^{\prime} \text {-DDT: aOR, } 2.5 ; 95 \% \text { Cl, } 1.0-6.3 \text {; for } p \text {, } p^{\prime} \text {-DDT: } \\
\text { aOR, } 2.1 ; 95 \% \text { Cl, } 1.0-4.5 \text { ). The odds ratios for girls } \\
\text { were not significant. }\end{array}$ \\
\hline
\end{tabular}


Table 2. Epidemiological evidence for the association among EDCs and childhood obesity (continued)

\begin{tabular}{|c|c|c|c|c|}
\hline Author/Year & $\begin{array}{l}\text { Population/ } \\
\text { study design }\end{array}$ & Location & Objects & Measured EDCs \\
\hline Wang $^{48 /} / 2012$ & $\begin{array}{l}\text { 2,921/cross- } \\
\text { sectional study }\end{array}$ & Shanghai, China & Age $8-15$ years & BPA \\
\hline $\mathrm{Li}^{611} / 2015$ & $\begin{array}{c}2,898 \\
\text { /cohort study }\end{array}$ & United States & $\begin{array}{l}\text { Children (6-19 } \\
\text { years old) }\end{array}$ & Triclosan \\
\hline $\begin{array}{l}\text { Tang- } \\
\text { Péronard } \\
\text { /2014 }\end{array}$ & $\begin{array}{l}\text { 640/prospective } \\
\text { cohort study }\end{array}$ & Faroe Islands & $\begin{array}{c}\text { Pregnant women } \\
\text { who gave } \\
\text { birth between } \\
\text { November } 1997 \\
\text { to March } 2000\end{array}$ & $\begin{array}{c}\text { PCBs }(138,153 \text {, and } 180) \\
\text { and DDE }\end{array}$ \\
\hline
\end{tabular}

BPA was detected in $84.9 \%$ of urine samples with a median concentration of $0.60 \mathrm{ng} / \mathrm{mL}$. Urinary BPA was positively associated with children BMl $(\beta=0.02,95 \% \mathrm{Cl}, 0.001-0.038)$ aged $8-11$ years old.

Urinary triclosan was associated with aOR 0.34 $(95 \% \mathrm{Cl}, 0.05-0.64) \mathrm{kg} / \mathrm{m}^{2}$ lower level of BMI and $0.92(95 \% \mathrm{Cl}, 0.09-1.74) \mathrm{cm}$ smaller waist circumference in boys, and a $0.62(95 \% \mathrm{Cl}, 0.31-$ $0.94) \mathrm{kg} / \mathrm{m}^{2}$ lower level of BMI and $1.32(95 \% \mathrm{Cl}$, 0.54-2.09) cm smaller waist circumference in girls.

Serum PCBs was positively associated with increased $\mathrm{BMI}(\beta=2.07 ; 95 \% \mathrm{Cl}, 0.59-1.65)$ of 7-year-old girls with overweight mothers, and PCBs and DDE were also associated with an increased change in BMI from 5 to 7 years of age (PCB: $\beta=1.23,95 \% \mathrm{Cl}, 0.42-2.05 ; \mathrm{DDE}: \beta=1.11$, $95 \% \mathrm{Cl}, 0.30-1.92)$. PCBs was associated with increased waist circumference in girls with overweight mothers ( $\beta=2.48,95 \% \mathrm{Cl}, 1.10-3.85$ ) and normalweight mothers $(\beta=1.25,95 \% \mathrm{Cl}$, 0.04-2.45); DDE was associated with increased waist circumference only in girls with overweight mothers ( $\beta=2.21,95 \% \mathrm{Cl}, 0.84-3.56$ ).

\begin{tabular}{|c|c|c|c|c|}
\hline Valvi $i^{73)} / 2014$ & $\begin{array}{l}\text { 2,150/birth } \\
\text { cohort study }\end{array}$ & Spanish & $\begin{array}{l}\text { Pregnant women } \\
\text { (>16 years) }\end{array}$ & $\begin{array}{c}\text { DDT, DDE, HCB, } \\
\beta \text {-hexachlorocyclohexane, } \\
\text { and PCB congeners } 28, \\
52,101,118,138,153, \\
\text { and } 180\end{array}$ \\
\hline Warner ${ }^{74)} / 2014$ & $\begin{array}{l}601 / \text { longitudinal } \\
\text { birth cohort study }\end{array}$ & $\begin{array}{c}\text { California, } \\
\text { United States }\end{array}$ & $\begin{array}{c}\text { Pregnant women } \\
\text { (>18 years), their } \\
\text { newborns ( } 1-7 \\
\text { years) }\end{array}$ & $\begin{array}{c}o, p^{\prime}-\mathrm{DDT}, p_{1} p^{\prime}-\mathrm{DDT}, \\
p, p^{\prime}-\mathrm{DDE}\end{array}$ \\
\hline
\end{tabular}

\begin{tabular}{|c|c|c|c|c|}
\hline Lignell $^{87)} / 2013$ & $\begin{array}{l}\text { 413/cross-sectional } \\
\text { study }\end{array}$ & Swedish & $\begin{array}{l}\text { Pregnant women } \\
\text { and newborns }\end{array}$ & $\begin{array}{c}\text { PCB }(138,153 \text { and } 180) \\
\text { PBDE- }(-47,-99,-100 \\
-153)\end{array}$ \\
\hline Dallaire ${ }^{89} / 2014$ & $\begin{array}{l}\text { 548/prospective } \\
\text { cohort study }\end{array}$ & Inuit & $\begin{array}{l}\text { Children } \\
\text { (8-14 years) }\end{array}$ & PCB 153 \\
\hline
\end{tabular}

Erkin-Cakmak $^{96)}$ 224/longitudinal California, Pregnant women PBDEs (- 17,-28, -47,-66, The sum of four penta BDEs (-47,-99,-100,-153) /2015 birth cohort study United States (>18 years) and $-85,-99,-100,-153,-154$, their children and -183)
The serum concentration ( $\mathrm{ng} / \mathrm{g}$ lipid) of DDE in pregnancy is about $132 \pm 2.4$. Serum DDE was positively associated with the rapid growth in the total populations ( $\beta=1.13 ; 95 \% \mathrm{Cl}, 1.01-1.26)$, and overweight at 14 months age $(\beta=1.15 ; 95 \%$ $\mathrm{Cl}, 1.03-1.28)$.

Among boys, 10-fold increases in prenatal DDT and DDE concentrations were associated with increased odds of becoming overweight or obese (for $0, p^{\prime}$-DDT: aOR, 2.5; 95\% Cl, 1.0-6.3; for $p, p^{\prime}$-DDT: $\mathrm{aOR}, 2.1 ; 95 \% \mathrm{Cl}, 1.0-4.5)$. The odds ratios for girls were not significant.

Di-ortho PCBs in breast milk was positively associated with birth weight ( $\beta=143, P=0.03$ ); the total di-ortho PCBs in breast milk from the mothers was $103 \pm 54 \mathrm{ng} / \mathrm{g}$ lipid.

Children blood PCB-153 concentrations were associated with reduced weight $(\beta=-0.15$, $P \leq 0.01)$, height $(\beta=-0.39, P \leq 0.001)$ and head circumference $(\beta=-0.28, P \leq 0.001)$ during childhood.

concentration $\left(\log _{10}\right)$ in child serum was positively associated with overweight $(\mathrm{aOR}, 0.36$; $95 \% \mathrm{Cl}, 0.14-0.94)$, while inversely associated with $\mathrm{BMI}(\beta=0.44,95 \% \mathrm{Cl},-0.83$ to -0.06$)$ as well as waist circumference $(\beta=-0.35,95 \% \mathrm{Cl},-0.66$ to -0.04 ) at 7 years age; Besides, BDE -100 and BDE -153 was significantly associated with children overweight at age of 7 years with aOR 0.40 $(95 \% \mathrm{Cl}, 0.16-1.03)$ and $0.08(95 \% \mathrm{Cl}, 1.03-0.27)$ respectively. 
Table 2. Epidemiological evidence for the association among EDCs and childhood obesity (continued)

\begin{tabular}{|c|c|c|c|c|c|}
\hline Author/Year & $\begin{array}{l}\text { Population/ } \\
\text { study design }\end{array}$ & Location & Objects & Measured EDCs & Outcome (IDR/aOR; CI) \\
\hline $\begin{array}{l}\text { Vuong }^{97 /} \\
\text { /2016 }\end{array}$ & $\begin{array}{l}\text { 318/birth cohort } \\
\text { study }\end{array}$ & $\begin{array}{c}\text { Ohio, } \\
\text { United States }\end{array}$ & $\begin{array}{l}\text { Pregnant women } \\
\text { (>18 years) and } \\
\text { their children }\end{array}$ & $\begin{array}{c}\text { BDEs }-17,-28,-47,-66 \\
-85,-99,-100,-153,-154 \\
\text { and }-183\end{array}$ & $\begin{array}{l}\text { No statistically significant associations between } \\
\text { prenatal PBDEs and height or weight } z \text {-score. } \\
\text { A } 10 \text {-fold increase in maternal serum BDE-153 } \\
\text { was associated with lower BMI z-score ( } \beta=-0.36 \text {, } \\
95 \% \mathrm{Cl} \text {, }-0.60 \text { to }-0.13 \text { ) at } 2-8 \text { years, smaller waist } \\
\text { circumference ( } \beta=-1.81 \mathrm{~cm} ; 95 \% \mathrm{Cl} \text { - }-3.13 \text { to } \\
\text {-0.50) at } 4-8 \text { years, and lower percent body fat } \\
(\beta=-2.37 ; 95 \% \mathrm{Cl},-4.21 \text { to }-0.53) \text { at } 8 \text { years. }\end{array}$ \\
\hline
\end{tabular}

\begin{tabular}{|c|c|c|c|c|c|}
\hline $\begin{array}{l}\text { Braun }^{108)} \\
/ 2016\end{array}$ & $\begin{array}{l}\text { 468/prospective } \\
\text { cohort study }\end{array}$ & $\begin{array}{c}\text { Ohio, } \\
\text { United States }\end{array}$ & $\begin{array}{c}\text { Pregnant } \\
\text { women: } 16 \pm 3 \\
\text { weeks gestation; } \\
\text { >18 years old; } \\
\text { living in a home } \\
\text { built before } \\
\text { 1978; no history } \\
\text { of HIV infection; } \\
\text { not taking any } \\
\text { medications for } \\
\text { seizure or thyroid } \\
\text { disorders. }\end{array}$ & $\begin{array}{c}\text { PFOA, PFOS, PFNA, and } \\
\text { PFHXS }\end{array}$ & $\begin{array}{l}\text { Children born to women in the top two PFOA } \\
\text { tertiles had greater adiposity at } 8 \text { years than } \\
\text { children in the } 1 \text { st tertile. Waist circumference } \\
\text { (cm) was higher among children in the } 2 \text { nd } \\
\text { (PFOA, } 5.3 \mathrm{ng} / \mathrm{mL})(\beta=4.3 ; 95 \% \mathrm{Cl}, 1.7-6.9) \text { and } \\
\text { 3rd tertile (PFOA, } 9.4 \mathrm{ng} / \mathrm{mL})(\beta=2.2 ; 95 \% \mathrm{Cl} \text {, } \\
\text { 20.5-4.9) compared to children in the } 1 \mathrm{st} \text { tertile } \\
\text { (PFOA, } 3.3 \mathrm{ng} / \mathrm{mL}) \text {. Children in the top } 2 \text { PFOA } \\
\text { tertiles also had greater BMl gains from } 2 \text { to } \\
8 \text { years compared to children in the } 1 \text { st tertile } \\
\text { (P<0.05). No significantly association observed } \\
\text { between PFOS, PFNA, and PFHxS with adiposity } \\
\text { in children. }\end{array}$ \\
\hline $\begin{array}{l}\text { Manzano- } \\
\text { Salgado } \\
\text { /2017 }\end{array}$ & $\begin{array}{c}\text { 2,150/birth cohort } \\
\text { study }\end{array}$ & $\begin{array}{c}\text { Gipuzkoa, } \\
\text { Sabadell, and } \\
\text { Valencia, Spanish }\end{array}$ & $\begin{array}{c}\text { Pregnant women } \\
\text { (16 years or } \\
\text { older) }\end{array}$ & $\begin{array}{c}\text { PFHXS, PFOS, PFOA, and } \\
\text { PFNA }\end{array}$ & $\begin{array}{l}\text { The most abundant compounds are PFOS and } \\
\text { PFOA with geometric mean concentrations are } \\
5.80 \text { and } 2.32 \mathrm{ng} / \mathrm{mL} \text {, respectively. Prenatal serum } \\
\text { PFHxS was positively associated with children } \\
\text { serum triglycerides } z \text {-score }(\beta=0.11,95 \% \mathrm{Cl} \text {, } \\
0.01-0.21) \text {. }\end{array}$ \\
\hline
\end{tabular}

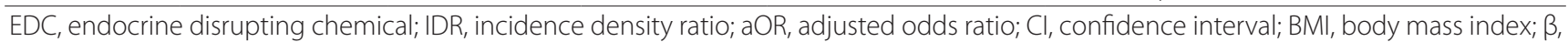
regression coefficient; MWP, molecular-weight phthalates; LMP, low molecular-weight phthalate; MEP, monoethyl phthalate: MBP, monon-butyl phthalate: MCPP, mono-(3-carboxypropyl): MBzP, mono-benzyl phthalate: MEHP, mono-(2-ethylhexyl) phthalate: MEOHP, mono(2ethyl-5-oxohexyl) phthalate: MECPP, mono(2-ethyl-5-carboxy-pentyl) phthalate: MEHHP, mono(2-ethyl-5-hydroxyhexyl) phthalate; DEHP, di-2-ethylhexyl phthalate; MMP, monomethyl phthalates; MnBP, mono-n-butyl phthalate; MiBP, mono-isobutyl phthalate; MCNP, mono(carboxynonyl) phthalate; MCOP, mono-(carboxyoctlyl) phthalate; BPA, bisphenol A; HCB, hexachlorobenzene; PCB, polychlorinated biphenyl; DDE, dichlorodiphenyldichloroethylene; DDT, dichlorodiphenyltrichloroethane; PBDE, Polybrominated diphenyl ether; PFOA, perfluorooctanoic acid; PFOS, perfluorooctane sulfonic acid; PFNA, perfluorononanoic acid; PFHxS, perfluorohexanesulfonic acid; $p, p^{\prime}$-DDT, 1,1,1-trichloro-2,2-bis(p-chlorophenyl)-ethane; o,p'-DDT, 1,1,1-trichloro-2-(p-chlorophenyl)-2-(o-chlorophenyl)-ethane.

and personal care products such as toothpastes, cosmetics, soaps, surgical cleaning treatment reagents and toys (Table 1$){ }^{55)}$ Similar to BPA, its biological half-life is very short ( $<24$ hours), and the majority $(24 \%-83 \%)$ was excreted in urine after 4 days exposure. ${ }^{56)}$ An individual can also be exposed to triclosan via skin contact. ${ }^{57)}$

Recent studies have suggested triclosan may be toxic to humans in addition to having antibacterial activity. ${ }^{58)}$ Pregnant rats exposed to triclosan from 8 days before mating to lactation day 21 developed primary hypothyroidism with decreased total serum T4 and T3 level. Pups also had a lower body weight on postnatal day 20 than that were not exposed to triclosan. ${ }^{59)}$ Although intrauterine exposure to triclosan was associated with reduced body weight in offspring, male triclosan-exposed rats were $12.5 \%$ heavier at 4 months $(P<0.001)$ than their unexposed counterparts, while females were $19 \%$ heavier for at 8 months than their unexposed counterparts $(P=0.01){ }^{60)}$

In a cross-sectional analysis of the US National Health and Nutritional Examination Surveys involving 7,964 participants, there was an inverse association between urinary triclosan level and obesity in children aged $6-19$ years $(\beta=-0.47,95 \% \mathrm{CI},-0.69$ to -0.26 ) (Table 2) ${ }^{61)}$ This finding was replicated in other cohort studies with possible gender difference; girls with a high urine triclosan level $(>13.83 \mu \mathrm{g} / \mathrm{mL})$ had a reduced plasma leptin level $(\beta=0.4,95 \% \mathrm{CI}, 0.2-1.1){ }^{62,63)}$ Taken together, these data indicate an inconsistent relationship between triclosan exposure and childhood obesity, perhaps due to variations in study design and/or participants' characteristics.

\section{Persistent organic pollutants}

POPs are EDCs that persist in the environment and tend to bioaccumulate through food chain. ${ }^{64)}$ Due to their lipophilicity, most POPs can accumulate in adipose tissue, which then act as a toxicity pool. ${ }^{65)}$

\section{Dichlorodiphenyltrichloroethane}

Dichlorodiphenyltrichloroethane (DDT) belongs to the 
organochlorine pesticides group and refers to a mixture of 1,1,1-trichloro-2,2-bis( $\mathrm{p}$-chlorophenyl)-ethane ( $p, p^{\prime}$-DDT) and 1,1,1-trichloro-2-(p-chlorophenyl)-2-(o-chlorophenyl)ethane $\left(o, p^{\prime}\right.$-DDT). Although the usage of DDT has been banned worldwide since the last century, it is still commonly used in malaria-endemic countries such as sub-Saharan Africa and India. ${ }^{66)}$ Of note, its half-life in the atmosphere and soil can be as long as 2.5 years and 20-30 years, respectively (Table 1). ${ }^{67)}$ Previous studies revealed that DDT posed negative effects on the reproductive system by altering endometrial function through kinase transduction pathway via an estrogen receptorindependent mechanism. ${ }^{68,69)}$ DDT could increase the gene expressions regulating adipogenesis such as peroxisomeproliferator activated receptor- $\gamma(\operatorname{PPAR} \gamma)$ and CCAAT/ enhancer-binding protein a $(\mathrm{C} / \mathrm{EBP} \alpha)$, enhance adipocyte differentiation from preadipocytes and adipogenic stem cells, which resulted in increased cellular uptake of fatty acids. ${ }^{70,71)}$

Several studies have demonstrated that prenatal exposure to DDT and dichlorodiphenyldichloroethylene (DDE) is associated with childhood obesity, ${ }^{20,72,73)}$ with possible gender differences. Every 10-fold increase in prenatal DDT and DDE concentrations was positively associated with increased odds of becoming overweight or obesity in boys (for o,p'-DDT, adjusted odds ratio [aOR], 2.5; 95\% CI, 1.0-6.3; for p,p'-DDT, aOR, 2.1; 95\% CI, 1.0-4.5), but not reported in girls. ${ }^{74)}$ This obesogenic effect was evident in the first 6 months after birth and might persist until teenage or adulthood. ${ }^{20,74,75)}$ However, isomers of DDT may have different effects. Every unit increase in p,p'DDT was associated with increased birth weight $\beta=274 \mathrm{~g}(95 \%$ CI, 122-425), while exposure to either o,p'-DDT was associated with decreased birth weight $\beta=-153 \mathrm{~g}(95 \% \mathrm{CI},-296$ to -10$){ }^{76}{ }^{7}$ Given the similarity in molecular structure between DDT and thyroid hormones, it has been postulated that DDT may promote obesity via disruption of thyroid homeostasis, although this requires confirmation in future mechanistic studies. ${ }^{77,78)}$

\section{Polychlorinated biphenyls}

Polychlorinated biphenyls (PCBs) are derived from biphenyl, where the hydrogen atoms of biphenyl are replaced by chlorine atoms to form 209 different congeners. PCBs are widely employed in industrial production (transformers and large capacitors), nominally closed systems (hydraulic fluids and lubricants) and open applications (carbonless copy paper) (Table 1) ${ }^{79)}$ PCBs have been banned since 2001, after the Stockholm Convention. ${ }^{80)}$ They have long half-lives $(0.4-11.4$ years in humans and $1-20$ years in soil). ${ }^{81-84)}$ Due to their lipophilicity, PCBs tend to accumulate in adipose tissue. Exposure to PCBs could promote adipogenesis and increase the release of inflammatory cytokines and lipid accumulation during adipocytes differentiation. ${ }^{64,85,86}$

In a cross-sectional study involving 526 mother-child pairs, prenatal exposure to di-ortho PCBs (including PCB-138, $-153,-180)$ was significantly associated with increased birth weight ( $\beta=137 \mathrm{~g}$; 95\% CI, 76-198; $P=0.02){ }^{87)}$ This was further supported by several prospective cohort studies that reported the detrimental effect of prenatal PCBs exposure on the development of obesity during neonatal period, which might persist until childhood (Table 2). ${ }^{72,88}$ By contrast, in another prospective cohort study in the Inuit population, plasma PCB153 level was inversely associated with body weight during childhood (Table 2) ${ }^{89)}$ A similar trend was found in a pooled analysis of seven European cohort studies; postnatal PCB 153 exposure was associated with a reduced weight-for-age $z$-score $(\beta=-0.10 ; 95 \% \mathrm{CI},-0.19$ to -0.01 , for every interquartile range increase of $183 \mathrm{ng} / \mathrm{g}$ lipid). ${ }^{90)}$

Different PCB congeners could have different effects on childhood obesity. Therefore, more epidemiological studies are needed to clarify the obesogenic effects of different congeners and total effects of PCBs mixture.

\section{Polybrominated diphenyl ethers}

Polybrominated diphenyl ethers (PBDEs) are organobromine compounds that have been extensively applied as flame retardants in consumer products including furniture foam, plastics, electronics and textiles (Table 1). ${ }^{91)}$ Use of PBDEs has been banned since 2004. However, they continue to enter the environment from consumer products and waste. ${ }^{92)}$ Similar to PCBs, replacement of hydrogen atoms by bromine atoms in biphenyl ethers generates 209 congeners of PBDEs. In general, the biological half-life of PBDEs is long, which ranges from 1.8-3 years for BDE-47 to 6.6-11.7 years for BDE-153. ${ }^{93)}$

Infants $(73 \pm 7 \mathrm{ng} / \mathrm{g}$ lipid $)$ and young children $(28 \pm 8 \mathrm{ng} / \mathrm{g}$ lipid) had higher concentration of total PBDEs than adults ( $15 \pm 5$ $\mathrm{ng} / \mathrm{g}$ lipid) after exposure via maternal transfer and breast milk consumption. ${ }^{94)} \mathrm{BDE}-47,-99,-100$, and -153 were the most abundantly detected congeners. ${ }^{95)}$ In a US longitudinal birth cohort involving 224 mother-child pairs, every 10 -fold increase in maternal serum PBDEs (including BDE-47, -99, -100, -153 ) had an inverse association with BMI $z$-scores in girls $(\beta=-0.41$; 95\% CI, -0.87 to -0.05 ) (Table 2). ${ }^{96)}$ A cohort study involving 413 mothers in Sweden demonstrated that PBDEs (sum of BDE-47, $-99,-100$, and -153 ) level in breast milk were inverse associated with birth weight in the multivariate model ( $\beta=-106 ; 95 \% \mathrm{CI}$, -158 to -54$).{ }^{87)}$ Another cohort study involving 318 motherchild pairs reported no statistically significant associations observed between prenatal PBDEs (including BDEs-28, -47, -99, $-100,-153)$ and birth weight $z$-score, whereby a 10 -fold increase in maternal serum BDE-153 was associated with a lower BMI $z$-score at 2-8 years, decreased waist circumference at $4-8$ years, and decreased body fat percentage at 8 years (Table 2). ${ }^{97)}$

Our research group and others have demonstrated that PBDEs induced in vitro adipocytes differentiation by increasing the expressions of genes involved in the adipogenesis and lipid accumulation. ${ }^{98-100)}$ In mice models, prenatal exposure of BDE 47 worsened hepatic steatosis and metabolic profiles in the offspring, possibly via the alteration of gut microbiome and impairment of insulin sensitivity. ${ }^{101,102)}$ In male rats, a low dose of BDE 47 increased plasma insulin-like growth factor 
1 level and impaired glucose metabolism. ${ }^{103,104)}$ These results suggest that BDE 47 can be an environmental obesogen, while the obesogenic effects of other PBDEs congeners remain to be verified in epidemiological and laboratory studies.

\section{Per- and polyfluoroalkyl substances}

Per- and polyfluoroalkyl substances (PFAS) belong to a class of synthetic fluorinated chemicals that are widely employed as stain- or oil-resistant coating materials for textiles, carpet, food containers and industrial surfactants. ${ }^{105)}$ The biological half-life of PFAS is more than 4 years. Given their relatively stable structure, PFAS are extremely resistant to chemical and biological degradation, with high bioaccumulation in human body through the food chain. ${ }^{105,106)}$ Four types of PFAS including perfluorooctanoic acid (PFOA), perfluorooctane sulfonic acid (PFOS), perfluorononanoic acid (PFNA), and perfluorohexane sulfonic acid (PFHxS), are the most universally detected in the serum of pregnant women and children as well as in general population. ${ }^{107-109)}$

Compared to health-based guidance of $0.04 \mu \mathrm{g} / \mathrm{L}$ for PFOA in drinking water, PFOS and PFOA are the most frequently detected congeners in the PFAS family and their geometric mean concentrations in pregnant women are 5.80 and $2.32 \mathrm{ng} /$ $\mathrm{mL}$ respectively, while the mean concentration of PFNA and PFHxS are 0.66 and $0.61 \mathrm{ng} / \mathrm{mL}^{1{ }^{110)}}$ Excess maternal PFOA exposure was associate with increased waist circumference $(\beta=4.3 ; 95 \% \mathrm{CI}, 1.7-6.9)$ in children at 8 years old (Table 2$).{ }^{108)}$ Furthermore, high prenatal PFAS, PFOA and PFOS levels were associated with increased serum total cholesterol, low-density lipoprotein cholesterol, and triglyceride levels in children. ${ }^{110,111)}$ Interestingly, another prospective cohort study involving 665 mother-child pairs observed inverse associations between PFOS or PFOA and homeostatic model assessment of insulin resistance when children were around 7 years old $(\beta=-10.1,95 \%$ CI, -16.4 to -3.3 ; and $\beta=-0.1,95 \% \mathrm{CI},-17.3$ to -2.3 for PFOS and PFOA, respectively). ${ }^{112)}$

In animal models, PFOA, PFOS and perfluoroalkyl acids increase lipid accumulation, promote insulin resistance and induce adipocytes differentiation, resulting in obesity. ${ }^{113-116)}$ However, in utero exposure to C57BL/6J-Min/+ (multiple intestinal neoplasia) mice with either PFOS or PFOA did not significantly increase the body weight of offspring. ${ }^{117)}$ Therefore, the obesogenic effects of PFOA and PFOS need to be verified with additional animal studies and epidemiological data.

\section{Possible mechanisms linking POPs, obesity, and diabetes}

There are several postulated mechanisms that can explain the effects of EDCs on early-life obesity, including mitochondrial dysfunction and epigenetic regulation.

\section{Mitochondrial dysfunction and oxidative stress}

Mitochondrial dysfunction can induce the development of cardiometabolic diseases including obesity, diabetes and cancer. ${ }^{118)}$ Mitochondrial dysfunction increases the accumulation of diacylglycerol (metabolites of fatty acids metabolism) ${ }^{119)}$ and reactive oxygen species (ROS), ${ }^{120)}$ particularly in insulinresistant tissues (such as liver tissue). ${ }^{118)}$

In obese mice, exposure to a PCB mixture (Aroclor 1260) impaired mitochondrial function and increased adipokines level, which could mediate inflammation and insulin resistance. ${ }^{121)}$ A study in $\mathrm{C} 57 \mathrm{BL} / 6 \mathrm{~J}$ mice demonstrated that visceral obesity, insulin resistance and glucose intolerance occurred when mice were fed salmon contaminated with PCBs (PCB-28, -52, -101,-138, -153, -180). ${ }^{122)}$ Taken together, these findings suggest that mitochondrial dysfunction is one of the key factors in the development of obesity associated with chronic exposure to POPs.

Oxidative stress also contributes to the development of obesity. ${ }^{123,124)}$ Multiple studies showed that ROS such as $\mathrm{H}_{2} \mathrm{O}_{2}$ can induce adipocyte differentiation and lipid peroxidation, leading to obesity and metabolic syndrome. ${ }^{123,125-128)}$ In addition to mitochondrial dysfunction, ${ }^{120,129)}$ ROS increases the transcriptional activity of PPAR $\gamma$ and $\mathrm{C} / \mathrm{EBP} \alpha$, which are the key transcriptional factors for adipogenesis. ${ }^{100,130,131)}$ Oxidation stress is often correlated with DNA oxidation because obesity causes significant oxidative stress, oxidative DNA damage, and changes of DNA methylation pattern in the tissue. ${ }^{126,132)}$ BDE-47 has been reported to increase the intracellular and mitochondrial ROS levels, adipocyte differentiation, lipid peroxidation, and DNA oxidation. ${ }^{100,133,134)}$ Importantly, inhibition of mitochondrial ROS production suppressed BDE47 -induced lipid accumulation and insulin resistance. ${ }^{100)}$ These results were confirmed by a decreased ratio of GSH to GSSG, which are biomarker of oxidative stress.

\section{DNA methylation}

DNA methylation, an epigenetic mechanism, involves addition of methyl groups to DNA, thereby modifying the activity of the DNA segment without changing the sequence. This can repress gene transcription, especially when methylation sites are located in a promoter region. Many POPs and BPA can induce DNA methylation. ${ }^{135)}$ Among 70 general workers in Arctic Council (which monitored the levels of pollutants in all Arctic environment), high serum POPs levels were associated with global DNA hypomethylation. ${ }^{136)}$ An inverse relationship was found between plasma levels of methylation of cytosine residues and many POPs including $\mathrm{p}, \mathrm{p}^{\prime}-\mathrm{DDT}$.

In a mouse model with the 3T3-L1 cell line, exposure to BDE-47 and PCB-153 altered DNA methylation levels. ${ }^{99,135)}$ Three hypomethylation $\mathrm{CpG}$ sites were located in the promoter region of PPAR $\gamma 2$, which is the key transcription 
factor for adipogenesis. ${ }^{99,135)}$ In vitro studies had demonstrated that PFOS and PFOA induced adipocyte differentiation via DNA methylation and Nrf2 pathways. ${ }^{115,116,135)}$ Thus, DNA methylation may be one of the mechanisms by which organic pollutants predispose animals to obesity.

\section{Conclusions}

This is epidemiological and preclinical evidence that perinatal exposure to EDCs has detrimental effects in children. Earlylife exposure to EDCs may impose an increased risk of obesity in later life, likely via impaired mitochondrial function and epigenetic dysregulation. Well-designed animal and prospective cohort studies are needed to provide more mechanistic insights on the relationships between EDCs and childhood obesity. Heightened efforts from governments and other stakeholders are warranted to formulate effective health policy and disseminate health education programs to raise public awareness to protect our youth from the detrimental effects of EDCs.

\section{Acknowledgments}

This work was supported by the grants from Mr. Kwok Yat Wai and Madam Kwok Chung Bo Fun Graduate School Development Fund, Hong Kong Baptist University; National Natural Science Foundation of China (General Program 21577115 and 21477101); the Research Grant Council of Hong Kong (RGC GRF 463612, 14104314, 12300114); Faculty Research Grants from the Hong Kong Baptist University (FRG2/15-16/067; FRG2/16-17/049; FRG2/17-18/072); Hong Kong Health and Medical Research Fund (HMRF/ 03144376); and HKASO research grant 2015-16.

\section{References}

1. Daniels SR, Arnett DK, Eckel RH, Gidding SS, Hayman LL, Kumanyika S, et al. Overweight in children and adolescents: pathophysiology, consequences, prevention, and treatment. Circulation 2005;111:1999-2012.

2. Must A. Does overweight in childhood have an impact on adult health? Nutr Rev 2003;61:139-42.

3. Berenson GS, Srinivasan SR, Bao W, Newman WP 3rd, Tracy RE, Wattigney WA. Association between multiple cardiovascular risk factors and atherosclerosis in children and young adults. The Bogalusa Heart Study. N Engl J Med 1998;338:1650-6.

4. Lauer RM, Lee J, Clarke WR. Factors affecting the relationship between childhood and adult cholesterol levels: the Muscatine Study. Pediatrics 1988;82:309-18.

5. Lauer RM, Clarke WR. Childhood risk factors for high adult blood pressure: the Muscatine Study. Pediatrics 1989;84:633-41.

6. Goodman E, Whitaker RC. A prospective study of the role of depression in the development and persistence of adolescent obesity. Pediatrics 2002;110:497-504.

7. GBD 2015 Obesity Collaborators, Afshin A, Forouzanfar MH, Reitsma MB, Sur P, Estep K, et al. Health effects of overweight and obesity in 195 countries over 25 years. N Engl J Med 2017;377:13-27.

8. Heymsfield SB, Wadden TA. Mechanisms, pathophysiology, and management of obesity. N Engl J Med 2017;376:25466.

9. Janssen I, Katzmarzyk PT, Boyce WF, Vereecken C, Mulvihill C, Roberts C, et al. Comparison of overweight and obesity prevalence in school-aged youth from 34 countries and their relationships with physical activity and dietary patterns. Obes Rev 2005;6:123-32.

10. Anderson PM, Butcher KE. Childhood obesity: trends and potential causes. Future Child 2006;16:19-45.

11. La Merrill M, Birnbaum LS. Childhood obesity and environmental chemicals. Mt Sinai J Med 2011;78:22-48.

12. Valvi D, Mendez MA, Martinez D, Grimalt JO, Torrent M, Sunyer J, et al. Prenatal concentrations of polychlorinated biphenyls, DDE, and DDT and overweight in children: a prospective birth cohort study. Environ Health Perspect 2012;120:451-7.

13. Scinicariello F, Buser MC. Urinary polycyclic aromatic hydrocarbons and childhood obesity: NHANES (20012006). Environ Health Perspect 2014;122:299-303.

14. Verhulst SL, Nelen V, Hond ED, Koppen G, Beunckens $\mathrm{C}$, Vael $\mathrm{C}$, et al. Intrauterine exposure to environmental pollutants and body mass index during the first 3 years of life. Environ Health Perspect 2009;117:122-6.

15. Halldorsson TI, Rytter D, Haug LS, Bech BH, Danielsen I, Becher G, et al. Prenatal exposure to perfluorooctanoate and risk of overweight at 20 years of age: a prospective cohort study. Environ Health Perspect 2012;120:668-73.

16. Zoeller RT, Brown TR, Doan LL, Gore AC, Skakkebaek NE, Soto AM, et al. Endocrine-disrupting chemicals and public health protection: a statement of principles from The Endocrine Society. Endocrinology 2012;153:4097-110.

17. Manickum T, John W. Occurrence, fate and environmental risk assessment of endocrine disrupting compounds at the wastewater treatment works in Pietermaritzburg (South Africa). Sci Total Environ 2014;468-469:584-97.

18. Rudel RA, Camann DE, Spengler JD, Korn LR, Brody JG. Phthalates, alkylphenols, pesticides, polybrominated diphenyl ethers, and other endocrine-disrupting compounds in indoor air and dust. Environ Sci Technol 2003;37:4543-53.

19. Geyer HJ, Rimkus GG, Scheunert I, Kaune A, Schramm KW, Kettrup A, et al. Bioaccumulation and occurrence of endocrine-disrupting chemicals (EDCs), persistent organic pollutants (POPs), and other organic compounds in fish and other organisms including humans. In: Beek B, Bohling S, editors. Bioaccumulation - New Aspects and Developments. Berlin: Springer; 2000. p. 1-166.

20. Mendez MA, Garcia-Esteban R, Guxens M, Vrijheid 
M, Kogevinas M, Goñi F, et al. Prenatal organochlorine compound exposure, rapid weight gain, and overweight in infancy. Environ Health Perspect 2011;119:272-8.

21. Romano ME, Savitz DA, Braun JM. Challenges and future directions to evaluating the association between prenatal exposure to endocrine disrupting chemicals and childhood obesity. Curr Epidemiol Rep 2014;1:57-66.

22. Agay-Shay K, Martinez D, Valvi D, Garcia-Esteban R, Basagaña $X$, Robinson O, et al. Exposure to endocrinedisrupting chemicals during pregnancy and weight at 7 years of age: a multi-pollutant approach. Environ Health Perspect 2015;123:1030-7.

23. Schettler T. Human exposure to phthalates via consumer products. Int J Androl 2006;29:134-9.

24. Trasande L, Sathyanarayana S, Jo Messito M, S Gross R, Attina TM, Mendelsohn AL. Phthalates and the diets of U.S. children and adolescents. Environ Res 2013;126:84-90.

25. Sathyanarayana S, Karr CJ, Lozano P, Brown E, Calafat AM, Liu F, et al. Baby care products: possible sources of infant phthalate exposure. Pediatrics 2008;121:e260-8.

26. Bornehag CG, Lundgren B, Weschler CJ, Sigsgaard T, Hagerhed-Engman L, Sundell J. Phthalates in indoor dust and their association with building characteristics. Environ Health Perspect 2005;113:1399-404.

27. Braun JM, Just AC, Williams PL, Smith KW, Calafat AM, Hauser R. Personal care product use and urinary phthalate metabolite and paraben concentrations during pregnancy among women from a fertility clinic. J Expo Sci Environ Epidemiol 2014;24:459-66.

28. Mankidy R, Wiseman S, Ma H, Giesy JP. Biological impact of phthalates. Toxicol Lett 2013;217:50-8.

29. Wolff MS, Engel SM, Berkowitz GS, Ye X, Silva MJ, Zhu C, et al. Prenatal phenol and phthalate exposures and birth outcomes. Environ Health Perspect 2008;116:1092-7.

30. Agency EP. Assessing and Managing Chemicals under TSCA. Phthalates [Internet]. Washington, DC: U.S. Environmental Protection Agency; 2012 Mar 14 [cited 2018 Nov 7]. Available from: https://www.epa.gov/assessingand-managing-chemicals-under-tsca/phthalates.

31. Dodson RE, Nishioka M, Standley LJ, Perovich LJ, Brody JG, Rudel RA. Endocrine disruptors and asthma-associated chemicals in consumer products. Environ Health Perspect 2012;120:935-43.

32. Buser MC, Murray HE, Scinicariello F. Age and sex differences in childhood and adulthood obesity association with phthalates: analyses of NHANES 2007-2010. Int J Hyg Environ Health 2014;217:687-94.

33. Zhang Y, Meng X, Chen L, Li D, Zhao L, Zhao Y, et al. Age and sex-specific relationships between phthalate exposures and obesity in Chinese children at puberty. PLoS One 2014;9:e104852.

34. Kim JH, Park H, Lee J, Cho G, Choi S, Choi G, et al. Association of diethylhexyl phthalate with obesity-related markers and body mass change from birth to 3 months of age. J Epidemiol Community Health 2016;70:466-72.
35. Hatch EE, Nelson JW, Qureshi MM, Weinberg J, Moore LL, Singer M, et al. Association of urinary phthalate metabolite concentrations with body mass index and waist circumference: a cross-sectional study of NHANES data, 1999-2002. Environ Health 2008;7:27.

36. Teitelbaum SL, Mervish N, Moshier EL, Vangeepuram $\mathrm{N}$, Galvez MP, Calafat AM, et al. Associations between phthalate metabolite urinary concentrations and body size measures in New York City children. Environ Res 2012;112:186-93

37. Deierlein AL, Wolff MS, Pajak A, Pinney SM, Windham GC, Galvez MP, et al. Longitudinal associations of phthalate exposures during childhood and body size measurements in young girls. Epidemiology 2016;27:492-9.

38. Smerieri A, Testa C, Lazzeroni P, Nuti F, Grossi E, Cesari S, et al. Di-(2-ethylhexyl) phthalate metabolites in urine show age-related changes and associations with adiposity and parameters of insulin sensitivity in childhood. PLoS One 2015;10:e0117831.

39. Schmidt JS, Schaedlich K, Fiandanese N, Pocar P, Fischer B. Effects of di(2-ethylhexyl) phthalate (DEHP) on female fertility and adipogenesis in $\mathrm{C} 3 \mathrm{H} / \mathrm{N}$ mice. Environ Health Perspect 2012;120:1123-9.

40. Valvi D, Casas M, Romaguera D, Monfort N, Ventura R, Martinez D, et al. Prenatal phthalate exposure and childhood growth and blood pressure: evidence from the Spanish INMA-Sabadell Birth Cohort Study. Environ Health Perspect 2015;123:1022-9.

41. von Goetz N, Wormuth M, Scheringer M, Hungerbühler $K$. Bisphenol a: how the most relevant exposure sources contribute to total consumer exposure. Risk Anal 2010;30:473-87.

42. Ehrlich S, Calafat AM, Humblet O, Smith T, Hauser R. Handling of thermal receipts as a source of exposure to bisphenol A. JAMA 2014;311:859-60.

43. Geens T, Apelbaum TZ, Goeyens L, Neels H, Covaci A. Intake of bisphenol A from canned beverages and foods on the Belgian market. Food Addit Contam Part A Chem Anal Control Expo Risk Assess 2010;27:1627-37.

44. Thayer KA, Doerge DR, Hunt D, Schurman SH, Twaddle NC, Churchwell MI, et al. Pharmacokinetics of bisphenol A in humans following a single oral administration. Environ Int 2015;83:107-15.

45. Hoepner LA, Whyatt RM, Widen EM, Hassoun A, Oberfield SE, Mueller NT, et al. Bisphenol A and Adiposity in an Inner-City Birth Cohort. Environ Health Perspect 2016;124:1644-50.

46. Volberg V, Harley K, Calafat AM, Davé V, McFadden J, Eskenazi B, et al. Maternal bisphenol a exposure during pregnancy and its association with adipokines in MexicanAmerican children. Environ Mol Mutagen 2013;54:621-8.

47. Trasande L, Attina TM, Blustein J. Association between urinary bisphenol A concentration and obesity prevalence in children and adolescents. JAMA 2012;308:1113-21.

48. Wang HX, Zhou Y, Tang CX, Wu JG, Chen Y, Jiang QW. 
Association between bisphenol A exposure and body mass index in Chinese school children: a cross-sectional study. Environ Health 2012;11:79.

49. Durando M, Kass L, Piva J, Sonnenschein C, Soto AM, Luque EH, et al. Prenatal bisphenol A exposure induces preneoplastic lesions in the mammary gland in Wistar rats. Environ Health Perspect 2007;115:80-6.

50. Somm E, Schwitzgebel VM, Toulotte A, Cederroth CR, Combescure C, Nef S, et al. Perinatal exposure to bisphenol a alters early adipogenesis in the rat. Environ Health Perspect 2009;117:1549-55.

51. Angle BM, Do RP, Ponzi D, Stahlhut RW, Drury BE, Nagel SC, et al. Metabolic disruption in male mice due to fetal exposure to low but not high doses of bisphenol A (BPA): evidence for effects on body weight, food intake, adipocytes, leptin, adiponectin, insulin and glucose regulation. Reprod Toxicol 2013;42:256-68

52. Zhao C, Xie P, Yong T, Wang H, Chung ACK, Cai Z. MALDI-MS imaging reveals asymmetric spatial distribution of lipid metabolites from bisphenol S-induced nephrotoxicity. Anal Chem 2018;90:3196-204.

53. Rochester JR, Bolden AL. Bisphenol S and F: A systematic review and comparison of the hormonal activity of bisphenol A substitutes. Environ Health Perspect 2015; 123:643-50.

54. Liu B, Lehmler HJ, Sun Y, Xu G, Liu Y, Zong G, et al. Bisphenol A substitutes and obesity in US adults: analysis of a population-based, cross-sectional study. Lancet Planet Health 2017; 1:e114-22.

55. Rodricks JV, Swenberg JA, Borzelleca JF, Maronpot RR, Shipp AM. Triclosan: a critical review of the experimental data and development of margins of safety for consumer products. Crit Rev Toxicol 2010;40:422-84.

56. Sandborgh-Englund G, Adolfsson-Erici M, Odham G, Ekstrand J. Pharmacokinetics of triclosan following oral ingestion in humans. J Toxicol Environ Health A 2006;69:1861-73.

57. Calafat AM, Ye X, Wong LY, Reidy JA, Needham LL. Urinary concentrations of triclosan in the U.S. population: $2003-$ 2004. Environ Health Perspect 2008;116:303-7.

58. James MO, Li W, Summerlot DP, Rowland-Faux L, Wood CE. Triclosan is a potent inhibitor of estradiol and estrone sulfonation in sheep placenta. Environ Int 2010;36:942-9.

59. Rodríguez PE, Sanchez MS. Maternal exposure to triclosan impairs thyroid homeostasis and female pubertal development in Wistar rat offspring. J Toxicol Environ Health A 2010;73:1678-88.

60. Rabaglino MB, Moreira-Espinoza MJ, Lopez JP, Garcia NH, Beltramo D. Maternal Triclosan consumption alters the appetite regulatory network on Wistar rat offspring and predispose to metabolic syndrome in the adulthood. Endocr J 2016;63:1007-16.

61. Li S, Zhao J, Wang G, Zhu Y, Rabito F, Krousel-Wood M, et al. Urinary triclosan concentrations are inversely associated with body mass index and waist circumference in the US general population: Experience in NHANES 2003-2010. Int J Hyg Environ Health 2015;218:401-6.

62. Shapiro GD, Arbuckle TE, Ashley-Martin J, Fraser WD, Fisher M, Bouchard MF, et al. Associations between maternal triclosan concentrations in early pregnancy and gestational diabetes mellitus, impaired glucose tolerance, gestational weight gain and fetal markers of metabolic function. Environ Res 2018;161:554-61.

63. Kalloo G, Calafat AM, Chen A, Yolton K, Lanphear BP, Braun JM. Early life Triclosan exposure and child adiposity at 8 Years of age: a prospective cohort study. Environ Health 2018;17:24.

64. Yang C, Kong APS, Cai Z, Chung ACK. Persistent organic pollutants as risk factors for obesity and diabetes. Curr Diab Rep 2017;17:132.

65. La Merrill M, Emond C, Kim MJ, Antignac JP, Le Bizec B, Clément K, et al. Toxicological function of adipose tissue: focus on persistent organic pollutants. Environ Health Perspect 2013;121:162-9.

66. Prato M, Polimeni M, Giribaldi G. DDT as anti-malaria tool: the bull in the China shop or the elephant in the room? London: INTECH Open Access Publisher; 2013.

67. Zhang C, Liu L, Ma Y, Li F. Using isomeric and metabolic ratios of DDT to identify the sources and fate of DDT in Chinese agricultural topsoil. Environ Sci Technol 2018;52:1990-6.

68. Ben Rhouma K, Tébourbi O, Krichah R, Sakly M. Reproductive toxicity of DDT in adult male rats. Hum Exp Toxicol 2001;20:393-7.

69. Tiemann U. In vivo and in vitro effects of the organochlorine pesticides DDT, TCPM, methoxychlor, and lindane on the female reproductive tract of mammals: a review. Reprod Toxicol 2008;25:316-26.

70. Kim J, Sun Q, Yue Y, Yoon KS, Whang KY, Marshall Clark J, et al. 4,4'-Dichlorodiphenyltrichloroethane (DDT) and 4,4'-dichlorodiphenyldichloroethylene (DDE) promote adipogenesis in 3T3-L1 adipocyte cell culture. Pestic Biochem Physiol 2016;131:40-5.

71. Strong AL, Shi Z, Strong MJ, Miller DF, Rusch DB, Buechlein AM, et al. Effects of the endocrine-disrupting chemical DDT on self-renewal and differentiation of human mesenchymal stem cells. Environ Health Perspect 2015;123:42-8.

72. Tang-Péronard JL, Heitmann BL, Andersen HR, Steuerwald U, Grandjean P, Weihe P, et al. Association between prenatal polychlorinated biphenyl exposure and obesity development at ages 5 and $7 \mathrm{y}$ : a prospective cohort study of 656 children from the Faroe Islands. Am J Clin Nutr 2014;99:5-13.

73. Valvi D, Mendez MA, Garcia-Esteban R, Ballester F, Ibarluzea J, Goñi F, et al. Prenatal exposure to persistent organic pollutants and rapid weight gain and overweight in infancy. Obesity (Silver Spring) 2014;22:488-96.

74. Warner M, Wesselink A, Harley KG, Bradman A, Kogut K, Eskenazi B. Prenatal exposure to dichlorodi- 
phenyltrichloroethane and obesity at 9 years of age in the CHAMACOS study cohort. Am J Epidemiol 2014;179:1312-22.

75. La Merrill M, Cirillo PM, Terry MB, Krigbaum NY, Flom JD, Cohn BA. Prenatal exposure to the pesticide DDT and hypertension diagnosed in women before age 50: a longitudinal birth cohort study. Environ Health Perspect 2013;121:594-9.

76. Kezios KL, Liu X, Cirillo PM, Cohn BA, Kalantzi OI, Wang Y, et al. Dichlorodiphenyltrichloroethane (DDT), DDT metabolites and pregnancy outcomes. Reprod Toxicol 2013;35:156-64.

77. Liu C, Shi Y, Li H, Wang Y, Yang K. p,p'-DDE disturbs the homeostasis of thyroid hormones via thyroid hormone receptors, transthyretin, and hepatic enzymes. Horm Metab Res 2011;43:391-6.

78. Grandone A, Santoro N, Coppola F, Calabrò P, Perrone L, Del Giudice EM. Thyroid function derangement and childhood obesity: an Italian experience. BMC Endocr Disord 2010;10:8.

79. Harrad SI, Sewart AP, Alcock R, Boumphrey R, Burnett V, Duarte-Davidson R, et al. Polychlorinated biphenyls (PCBs) in the British environment: sinks, sources and temporal trends. Environ Pollut 1994;85:131-46.

80. Porta M, Zumeta E. Implementing the stockholm treaty on persistent organic pollutants. Occup Environ Med 2002;59:651-2.

81. Müller MH, Polder A, Brynildsrud OB, Karimi M, Lie E, Manyilizu WB, et al. Organochlorine pesticides (OCPs) and polychlorinated biphenyls (PCBs) in human breast milk and associated health risks to nursing infants in Northern Tanzania. Environ Res 2017;154:425-34.

82. Arinaitwe K, Muir DCG, Kiremire BT, Fellin P, Li H, Teixeira C, et al. Prevalence and sources of polychlorinated biphenyls in the atmospheric environment of Lake Victoria, East Africa. Chemosphere 2018;193:343-50.

83. Kania-Korwel I, Lehmler HJ. Toxicokinetics of chiral polychlorinated biphenyls across different species--a review. Environ Sci Pollut Res Int 2016;23:2058-80.

84. Terzaghi E, Zanardini E, Morosini C, Raspa G, Borin S, Mapelli F, et al. Rhizoremediation half-lives of PCBs: Role of congener composition, organic carbon forms, bioavailability, microbial activity, plant species and soil conditions, on the prediction of fate and persistence in soil. Sci Total Environ 2018;612:544-60.

85. Bourez S, Van den Daelen C, Le Lay S, Poupaert J, Larondelle Y, Thomé JP, et al. The dynamics of accumulation of PCBs in cultured adipocytes vary with the cell lipid content and the lipophilicity of the congener. Toxicol Lett 2013;216:406.

86. Arsenescu V, Arsenescu RI, King V, Swanson H, Cassis LA. Polychlorinated biphenyl-77 induces adipocyte differentiation and proinflammatory adipokines and promotes obesity and atherosclerosis. Environ Health Perspect 2008;116:761-8.
87. Lignell S, Aune M, Darnerud PO, Hanberg A, Larsson SC, Glynn A. Prenatal exposure to polychlorinated biphenyls (PCBs) and polybrominated diphenyl ethers (PBDEs) may influence birth weight among infants in a Swedish cohort with background exposure: a cross-sectional study. Environ Health 2013;12:44.

88. Wohlfahrt-Veje C, Audouze K, Brunak S, Antignac JP, le Bizec B, Juul A, et al. Polychlorinated dibenzo-p-dioxins, furans, and biphenyls (PCDDs/PCDFs and PCBs) in breast milk and early childhood growth and IGF1. Reproduction 2014;147:391-9.

89. Dallaire R, Dewailly É, Ayotte P, Forget-Dubois N, Jacobson SW, Jacobson JL, et al. Growth in Inuit children exposed to polychlorinated biphenyls and lead during fetal development and childhood. Environ Res 2014;134:17-23.

90. Iszatt N, Stigum H, Verner MA, White RA, Govarts E, Murinova LP, et al. Prenatal and postnatal exposure to persistent organic pollutants and infant growth: a pooled analysis of seven European birth cohorts. Environ Health Perspect 2015;123:730-6.

91. Besis A, Samara C. Polybrominated diphenyl ethers (PBDEs) in the indoor and outdoor environments--a review on occurrence and human exposure. Environ Pollut 2012;169:217-29.

92. Abbasi G, Buser AM, Soehl A, Murray MW, Diamond ML. Stocks and flows of PBDEs in products from use to waste in the U.S. and Canada from 1970 to 2020. Environ Sci Technol 2015;49:1521-8.

93. Geyer HJ, Schramm KW, Darnerud PO, Aune M, Feicht EA, Fried KW, et al. Terminal elimination half-lives of the brominated flame retardants TBBPA, HBCD, and lower brominated PBDEs in humans. Organohalogen Compounds 2004;66:3867-72.

94. Toms LM, Harden F, Paepke O, Hobson P, Ryan JJ, Mueller JF. Higher accumulation of polybrominated diphenyl ethers in infants than in adults. Environ Sci Technol 2008;42:7510-5.

95. Darrow LA, Jacobson MH, Preston EV, Lee GE, Panuwet P, Hunter RE Jr, et al. Predictors of serum polybrominated diphenyl ether (PBDE) concentrations among children aged 1-5 years. Environ Sci Technol 2017;51:645-54.

96. Erkin-Cakmak A, Harley KG, Chevrier J, Bradman A, Kogut $\mathrm{K}$, Huen $\mathrm{K}$, et al. In utero and childhood polybrominated diphenyl ether exposures and body mass at age 7 years: the CHAMACOS study. Environ Health Perspect 2015;123:636-42.

97. Vuong AM, Braun JM, Sjödin A, Webster GM, Yolton K, Lanphear BP, et al. Prenatal polybrominated diphenyl ether exposure and body mass index in children up to 8 years of age. Environ Health Perspect 2016;124:1891-7.

98. Tung EW, Boudreau A, Wade MG, Atlas E. Induction of adipocyte differentiation by polybrominated diphenyl ethers (PBDEs) in 3T3-L1 cells. PLoS One 2014;9:e94583.

99. Kamstra JH, Hruba E, Blumberg B, Janesick A, Mandrup S, Hamers T, et al. Transcriptional and epigenetic mechanisms 
underlying enhanced in vitro adipocyte differentiation by the brominated flame retardant BDE-47. Environ Sci Technol 2014;48:4110-9.

100. Chunxue Yang, Chi-Ming Wong, Juntong Wei, Arthur C.K. Chung, Zongwei Cai. The brominated flame retardant BDE 47 upregulates purine metabolism and mitochondrial respiration to promote adipocyte differentiation. Science of The Total Environment 2018;644:1312-22.

101. McIntyre RL, Kenerson HL, Subramanian S, Wang SA, Kazami M, Stapleton HM, et al. Polybrominated diphenyl ether congener, BDE-47, impairs insulin sensitivity in mice with liver-specific Pten deficiency. BMC Obes 2015;2:3.

102. Wang D, Yan J, Teng M, Yan S, Zhou Z, Zhu W. In utero and lactational exposure to BDE-47 promotes obesity development in mouse offspring fed a high-fat diet: impaired lipid metabolism and intestinal dysbiosis. Arch Toxicol 2018;92:1847-60.

103. Suvorov A, Battista MC, Takser L. Perinatal exposure to low-dose 2,2',4,4'-tetrabromodiphenyl ether affects growth in rat offspring: what is the role of IGF-1? Toxicology 2009;260:126-31.

104. Ross MG, Desai M, Khorram O, McKnight RA, Lane RH, Torday J. Gestational programming of offspring obesity: a potential contributor to Alzheimer's disease. Curr Alzheimer Res 2007;4:213-7.

105. Buck RC, Franklin J, Berger U, Conder JM, Cousins IT, de Voogt P, et al. Perfluoroalkyl and polyfluoroalkyl substances in the environment: terminology, classification, and origins. Integr Environ Assess Manag 2011;7:513-41.

106. Olsen GW, Burris JM, Ehresman DJ, Froehlich JW, Seacat AM, Butenhoff JL, et al. Half-life of serum elimination of perfluorooctanesulfonate,perfluorohexanesulfonate, and perfluorooctanoate in retired fluorochemical production workers. Environ Health Perspect 2007;115:1298-305.

107. Mora AM, Oken E, Rifas-Shiman SL, Webster TF, Gillman MW, Calafat AM, et al. Prenatal exposure to perfluoroalkyl substances and adiposity in early and mid-childhood. Environ Health Perspect 2017;125:467-73.

108. Braun JM, Chen A, Romano ME, Calafat AM, Webster GM, Yolton K, et al. Prenatal perfluoroalkyl substance exposure and child adiposity at 8 years of age: The HOME study. Obesity (Silver Spring) 2016;24:231-7.

109. Worley RR, Moore SM, Tierney BC, Ye X, Calafat AM, Campbell S, et al. Per- and polyfluoroalkyl substances in human serum and urine samples from a residentially exposed community. Environ Int 2017;106:135-43.

110. Manzano-Salgado CB, Casas M, Lopez-Espinosa MJ, Ballester F, Iñiguez C, Martinez D, et al. Prenatal exposure to perfluoroalkyl substances and cardiometabolic risk in children from the Spanish INMA Birth Cohort Study. Environ Health Perspect 2017;125:097018.

111. Geiger SD, Xiao J, Ducatman A, Frisbee S, Innes K, Shankar A. The association between PFOA, PFOS and serum lipid levels in adolescents. Chemosphere 2014;98:78-83.

112. Fleisch AF, Rifas-Shiman SL, Mora AM, Calafat AM,
Ye X, Luttmann-Gibson H, et al. Early-life exposure to perfluoroalkyl substances and childhood metabolic function. Environ Health Perspect 2017;125:481-7.

113. Hines EP, White SS, Stanko JP, Gibbs-Flournoy EA, Lau C, Fenton SE. Phenotypic dichotomy following developmental exposure to perfluorooctanoic acid (PFOA) in female CD-1 mice: Low doses induce elevated serum leptin and insulin, and overweight in mid-life. Mol Cell Endocrinol 2009;304:97-105.

114. Wang L, Wang Y, Liang Y, Li J, Liu Y, Zhang J, et al. PFOS induced lipid metabolism disturbances in BALB/c mice through inhibition of low density lipoproteins excretion. Sci Rep 2014;4:4582.

115. Xu J, Shimpi P, Armstrong L, Salter D, Slitt AL. PFOS induces adipogenesis and glucose uptake in association with activation of Nrf2 signaling pathway. Toxicol Appl Pharmacol 2016;290:21-30.

116. Watkins AM, Wood CR, Lin MT, Abbott BD. The effects of perfluorinated chemicals on adipocyte differentiation in vitro. Mol Cell Endocrinol 2015;400:90-101.

117. Ngo HT, Hetland RB, Sabaredzovic A, Haug LS, Steffensen IL. In utero exposure to perfluorooctanoate (PFOA) or perfluorooctane sulfonate (PFOS) did not increase body weight or intestinal tumorigenesis in multiple intestinal neoplasia (Min/+) mice. Environ Res 2014;132:251-63.

118. Nunnari J, Suomalainen A. Mitochondria: in sickness and in health. Cell 2012;148:1145-59.

119. Itani SI, Ruderman NB, Schmieder F, Boden G. Lipidinduced insulin resistance in human muscle is associated with changes in diacylglycerol, protein kinase $\mathrm{C}$, and IkappaB-alpha. Diabetes 2002;51:2005-11.

120. Lim S, Cho YM, Park KS, Lee HK. Persistent organic pollutants, mitochondrial dysfunction, and metabolic syndrome. Ann NY Acad Sci 2010;1201:166-76.

121. Wahlang B, Prough RA, Falkner KC, Hardesty JE, Song M, Clair HB, et al. Polychlorinated biphenyl-xenobiotic nuclear receptor interactions regulate energy metabolism, behavior, and inflammation in non-alcoholic-steatohepatitis. Toxicol Sci 2016;149:396-410.

122. Ibrahim MM, Fjære E, Lock EJ, Naville D, Amlund H, Meugnier E, et al. Chronic consumption of farmed salmon containing persistent organic pollutants causes insulin resistance and obesity in mice. PLoS One 2011;6:e25170.

123. Furukawa S, Fujita T, Shimabukuro M, Iwaki M, Yamada Y, Nakajima Y, et al. Increased oxidative stress in obesity and its impact on metabolic syndrome. J Clin Invest 2004;114:1752-61.

124. Houstis N, Rosen ED. Reactive oxygen species play a causal role in multiple forms of insulin resistance. 2006; Nature 440:944-8.

125. Tormos KV, Anso E, Hamanaka RB, Eisenbart J, Joseph J, Kalyanaraman B, et al. Mitochondrial complex III ROS regulate adipocyte differentiation. Cell Metab 2011;14:53744.

126. Sankhla M, Sharma TK, Mathur K, Rathor JS, Butolia V, 
Gadhok AK, et al. Relationship of oxidative stress with obesity and its role in obesity induced metabolic syndrome. Clin Lab 2012;58:385-92.

127. Matsuda M, Shimomura I. Increased oxidative stress in obesity: implications for metabolic syndrome, diabetes, hypertension, dyslipidemia, atherosclerosis, and cancer. Obes Res Clin Pract 2013;7:e330-41.

128. Savini I, Gasperi V, Catani MV. In: Marcello MA, Cunha LL, Batista FD, Ward LS. Oxidative stress and obesity. Cham (Switzerland): Springer International Publishing; 2016:6586.

129. Aly HA, Domènech O. Cytotoxicity and mitochondrial dysfunction of 2,3,7,8-tetrachlorodibenzo-p-dioxin (TCDD) in isolated rat hepatocytes. Toxicol Lett 2009;191: 79-87.

130. Madsen MS, Siersbæk R, Boergesen M, Nielsen R, Mandrup S. Peroxisome proliferator-activated receptor $\gamma$ and $\mathrm{C} / \mathrm{EBPa}$ synergistically activate key metabolic adipocyte genes by assisted loading. Mol Cell Biol 2014;34:939-54.

131. Ali AT, Hochfeld WE, Myburgh R, Pepper MS. Adipocyte and adipogenesis. Eur J Cell Biol 2013;92:229-36.
132. Valavanidis A, Vlachogianni T, Fiotakis C. 8-hydroxy-2' -deoxyguanosine (8-OHdG): A critical biomarker of oxidative stress and carcinogenesis. J Environ Sci Health C Environ Carcinog Ecotoxicol Rev 2009;27:120-39.

133. Tagliaferri S, Caglieri A, Goldoni M, Pinelli S, Alinovi R, Poli D, et al. Low concentrations of the brominated flame retardants BDE-47 and BDE-99 induce synergistic oxidative stress-mediated neurotoxicity in human neuroblastoma cells. Toxicol In Vitro 2010;24:116-22.

134. He P, He W, Wang A, Xia T, Xu B, Zhang M, et al. PBDE-47-induced oxidative stress, DNA damage and apoptosis in primary cultured rat hippocampal neurons. Neurotoxicology 2008;29:124-9.

135. Bastos Sales L, Kamstra JH, Cenijn PH, van Rijt LS, Hamers T, Legler J. Effects of endocrine disrupting chemicals on in vitro global DNA methylation and adipocyte differentiation. Toxicol In Vitro 2013;27:1634-43.

136. Rusiecki JA, Baccarelli A, Bollati V, Tarantini L, Moore LE, Bonefeld-Jorgensen EC. Global DNA hypomethylation is associated with high serum-persistent organic pollutants in Greenlandic Inuit. Environ Health Perspect 2008;116:154752. 